Terrestrial Mollusk Surveys in Glacier National Park during 2008, including an Illustrated Key to All Documented Species

Prepared for:

Glacier National Park,

West Glacier, MT 59936

By:

Paul Hendricks

Montana Natural Heritage Program

Natural Resource Information System

Montana State Library

October 2009

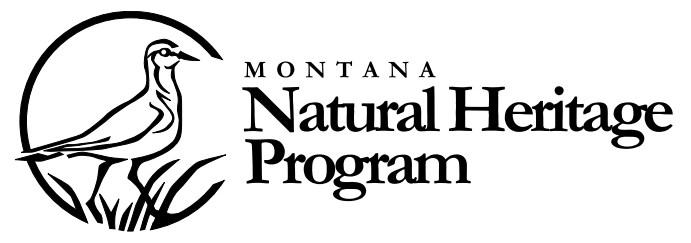





\section{Terrestrial Mollusk Surveys in Glacier National Park during 2008, including an Illustrated Key to All Documented Species}

Prepared for:

Glacier National Park, West Glacier, MT 59936

Agreement Number:

GLAC-00125

By:

Paul Hendricks

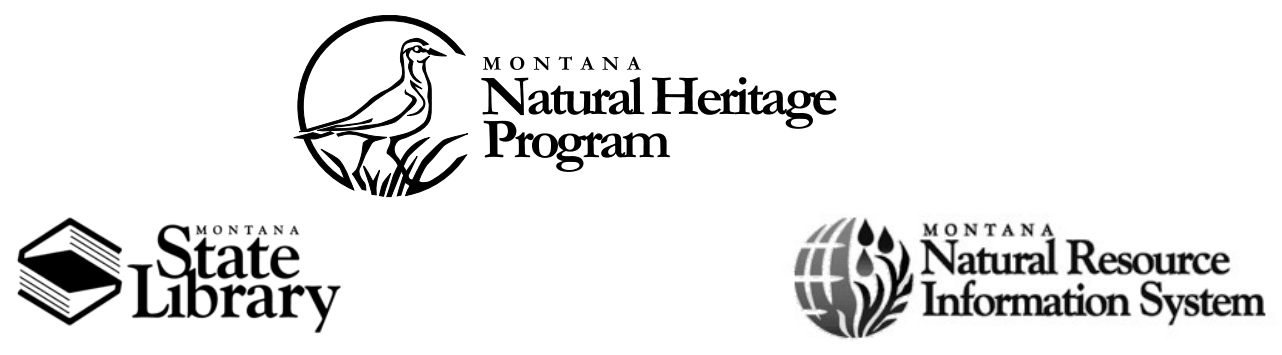

(C) 2009 Montana Natural Heritage Program

P.O. Box $201800 \bullet 1515$ East Sixth Avenue • Helena, MT 59620-1800 • 406-444-5354 
This document should be cited as follows:

Hendricks, Paul. 2009. Terrestrial Mollusk Surveys in Glacier National Park during 2008, including an Illustrated Key to All Documented Species. Report to Glacier National Park. Montana Natural Heritage Program, Helena, Montana. 6 pp. plus appendices. 


\section{Executive Summary}

An area within Montana lacking recent land snail surveys is Glacier National Park. No study of the terrestrial mollusk fauna has been undertaken in the park since the production of a mollusk checklist in the mid 1960's, and only one other study of the terrestrial mollusk fauna of the park was conducted prior to the production of the 1967 checklist: a brief survey in August 1916. Montana Natural Heritage Program (MTNHP) surveys on Forest Service lands during 2005-2007 indicated that several SOC taxa, none of which are on the 1967 checklist, were likely to occur within the boundaries of the park, and underscored the need for additional inventory to approach completeness of the Glacier National Park checklist. In addition, significant land cover changes (wildfire in particular) have occurred in Glacier National Park since the production of the 1967 checklist, and current status of all terrestrial mollusk species in response to this change is unknown.

The 1967 checklist included 14 species of terrestrial mollusks for Glacier National Park. Of these, three species found in 1919 had not been documented since then, but three species not reported in 1916 had been added, including the first non-native species, the exotic Giant Garden Slug (Limax maximus).

MTNHP land snail surveys were conducted during 13-18 October 2008, all in the western half of the park. The 20 site surveys resulted in detection of 369 individuals of 18 species. Six species were new to the park checklist: the snails Glossy Pillar (Cochlicopa lubrica) and Lovely Vallonia (Vallonia pulchella), and the slugs Brown-banded Arion
(Arion circumscriptus), Dusky Arion (A. subfuscus), Meadow Slug (Derocerus laeve), and Reticulate Taildropper (Prophysaon andersoni). An additional slug species previously undocumented in the park (Chocolate Arion, A. rufus) was seen and described in 2008 by park personnel in the Headquarters Area and could only be this species. Two species on the 1967 checklist were not detected in 2008: Shiny Tightcoil (Pristiloma wascoense) and Cross Vertigo (Vertigo modesta).

The checklist for land mollusks documented in Glacier National Park now includes 21 species, an expansion of 50\% over the 1967 checklist. The 2008 checklist includes 15 land snail species (one non-native) and six slug species (four non-native). Four of the seven species new to the checklist in 2008 are exotics (non-natives), and one (Reticulate Taildropper) is a Montana Animal Species of Concern.

Survey results helped fill gaps in documented distributions for several taxa, and contributed to the data sets used for production of new state-wide Predicted Distribution Models that are now under development. Survey results have been entered into the Montana Natural Heritage Program's Animal Point Observation Database. General data summaries for individual species can be seen on the Montana Field Guide and details on the survey locations and species detected can be found on the Montana Heritage Program's Tracker application; links to both can be found in the upper center of the Montana Heritage Program's Homepage at http:// mtnhp.org/ 


\section{ACKnowledgements}

The field assistance of Steve Gniadek and Tim Goddard (both of Glacier National Park) is greatly appreciated, as are the efforts of Steve to see this project succeed. Coburn Currier (MTNHP) processed field data sheets, entered data into the MTNHP databases, and formatted this report. The 2008 land mollusk surveys were conducted under the park-assigned study GLAC-00125, administered through the Rocky Mountain Cooperative Ecosystem Studies Unit (RM-CESU), based at the University of Montana. 


\section{Table of Contents}

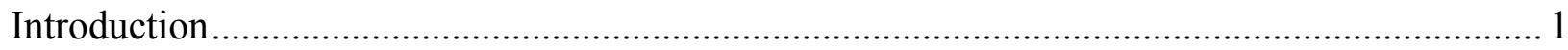

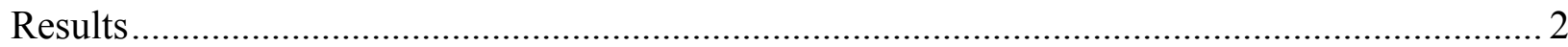

Nomenclatural changes since the 1967 checklist............................................................ 2

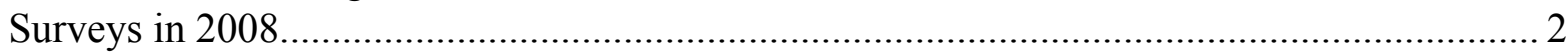

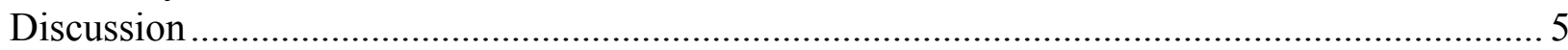

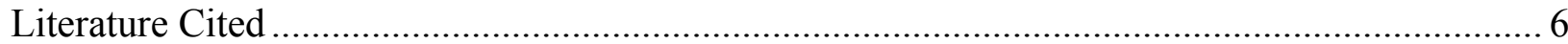

Appendix A. Survey locations for land snails in Glacier National Park, 2008

Appendix B. Illustrated dichotomous key to the terrestrial mollusks documented for Glacier National Park as of 2008

\section{List Of Figures}

Figure 1. Locations of surveys in Glacier National Park, October 2008 ............................ 3

\section{LisT OF TABLES}

Table 1. Nomenclatural changes for Glacier National Park land mollusks ............................ 2

Table 2. Land snails and slugs encountered west of the Continental Divide in Glacier

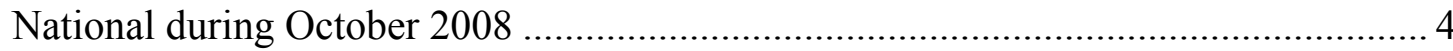





\section{INTRODUCTION}

Status of the land mollusk fauna of Montana has been largely ignored during the last 30 years. In 2003, with support of the U.S. Forest Service Northern Region, the Montana Natural Heritage Program (MTNHP) began reviewing the status of more than 75 land snail and slug species reported for the state. This status review has been followed by nearly-annual field surveys since 2005 , again with USFS support, to fill distribution gaps and sample intensively those habitats (such as mature and old-growth cedar-hemlock-grand fir forest) that appear to support the greatest diversity of species. Status review and surveys resulted in a list of 11 native land snails and 8 native slugs placed on the Montana Animal Species of Concern (SOC) List. Results of the USFS surveys were encouraging. Three native slugs and one snail were documented for the first time in Montana, and Global Ranks of five SOC species dropped from "at high risk" to a lesser status rank. The increased survey coverage also provided a foundation for the development of predictive distribution maps, which will guide future survey efforts by identifying landscapes likely to support SOC mollusks.

One of the areas lacking recent land snail surveys is Glacier National Park. No study of the terrestrial mollusk fauna has been undertaken in the park since the production of a mollusk checklist in the mid 1960's (Russell and Brunson 1967), and only one study of the terrestrial mollusk fauna of
Glacier National Park was conducted prior to the production of the 1967 checklist: a brief survey in August 1916 (Berry 1919). MTNHP surveys on Forest Service lands during 2005-2007 indicated that several SOC taxa, none of which are on the 1967 checklist, were likely to occur within the boundaries of the park, and underscored the need for additional inventory to approach completeness of the Glacier National Park checklist. In addition, significant land cover changes (wildfire in particular) have occurred in Glacier National Park since the production of the 1967 checklist, and current status of all terrestrial mollusk species in response to this change is unknown.

The work conducted in 2008 was intended as a pilot study to determine the possible presence of several SOC land snail species likely to occur in Glacier National Park, as well as to determine the continued presence of taxa appearing on the 1967 checklist. The work plan included training of Park Service personnel in survey and inventory techniques, as well as field identification of taxa encountered, so that the park could undertake additional survey work if and when resources became available. All survey sites were georeferenced with a GPS unit and documented with a digital photograph in order to eventually make them available on the Heritage Program's Tracker website as a long-term archive of habitat characteristics at the time of survey. 


\section{Results}

\section{Nomenclatural changes since the 1967 checklist}

The Russell and Brunson (1967) checklist included nomenclatural changes occurring after the publication of Berry's (1919) survey. Additional changes have occurred during the intervening years between the 1967 checklist and the MTNHP survey of 2008. To lessen confusion when cross-checking references, these changes are summarized in Table 1 ; sequence is alphabetical by scientific name as of 2008 for snails and slugs separately. Subspecies in the earlier lists are lumped under species names.

\section{Surveys in 2008}

Twenty sites were surveyed for land snails during 13-18 October 2008 (Fig. 1, Appendix 1). Elevation of sites was $3151-4100 \mathrm{ft}$, with 15 sites in or near the McDonald Creek drainage and five sites in the North Fork Flathead River drainage. Duration of surveys ranged from 30-150 personminutes (mean $=69$ person-minutes). Surveys were limited to west of the Continental Divide to avoid using valuable survey time in accessing the east side of the park (base of operations was Park Headquarters near West Glacier). Despite the lateness of the season, with early-morning frost

Table 1. Nomenclatural changes for Glacier National Park land mollusks. Blank space indicates the species was not reported up to that date; brackets indicate species was not detected on a subsequent survey.

\begin{tabular}{|c|c|c|c|}
\hline Common Name & $\begin{array}{l}\text { MTNHP } \\
(\mathbf{2 0 0 8 )}\end{array}$ & $\begin{array}{c}\text { Russell and Brunson } \\
\text { (1967) }\end{array}$ & $\begin{array}{c}\text { Berry } \\
\text { (1919) }\end{array}$ \\
\hline \multicolumn{4}{|l|}{ Snails } \\
\hline Suboval Ambersnail & Catinella vermeta & Succinea avara & \\
\hline Glossy Pillar & Cochlicopa lubrica & & \\
\hline Toothless Column & Columella edentula & Columella edentula & \\
\hline Forest Disc & Discus whitneyi & Discus cronkhitei & Pyramidula cronkhitei \\
\hline Brown Hive & Euconulus fulvus & Euconulus fulvus & Euconulus fulvus \\
\hline Spruce Snail & Microphysula ingersolli & Microphysula ingersolli & Thysanophora ingersolli \\
\hline Blue Glass & Nesovitrea binneyana & Retinella binneyana & Polita binneyana \\
\hline Subalpine Mountainsnail & Oreohelix subrudis & Oreohelix subrudis & Oreohelix cooperi \\
\hline Shiny Tightcoil & [Pristiloma wascoense] & Pristiloma wascoense & Polita chersinella \\
\hline Ribbed Spot & Punctum californicum & [Punctum californicum] & Punctum californicum \\
\hline Northwest Striate & Striatura pugetensis & [Striatura pugetensis] & Striatura milium \\
\hline Lovely Vallonia & Vallonia pulchella & & \\
\hline Cross Vertigo & [Vertigo modesta] & [Vertigo modesta] & Vertigo modesta \\
\hline Western Glass-snail & Vitrina pellucida & Vitrina limpida & Vitrina alaskana \\
\hline Quick Gloss & Zonitoides arboreus & Zonitoides arboreus & Zomitoides arborea \\
\hline \multicolumn{4}{|l|}{ Slugs } \\
\hline Brown-banded Arion & Arion circumscriptus & & \\
\hline Chocolate Arion & Arion rufus & & \\
\hline Dusky Arion & Arion subfuscus & & \\
\hline Meadow Slug & Derocerus laeve & & \\
\hline Giant Gardenslug & Limax maximus & Limax maximus & \\
\hline Reticulate Taildropper & Prophysaon andersoni & & \\
\hline
\end{tabular}




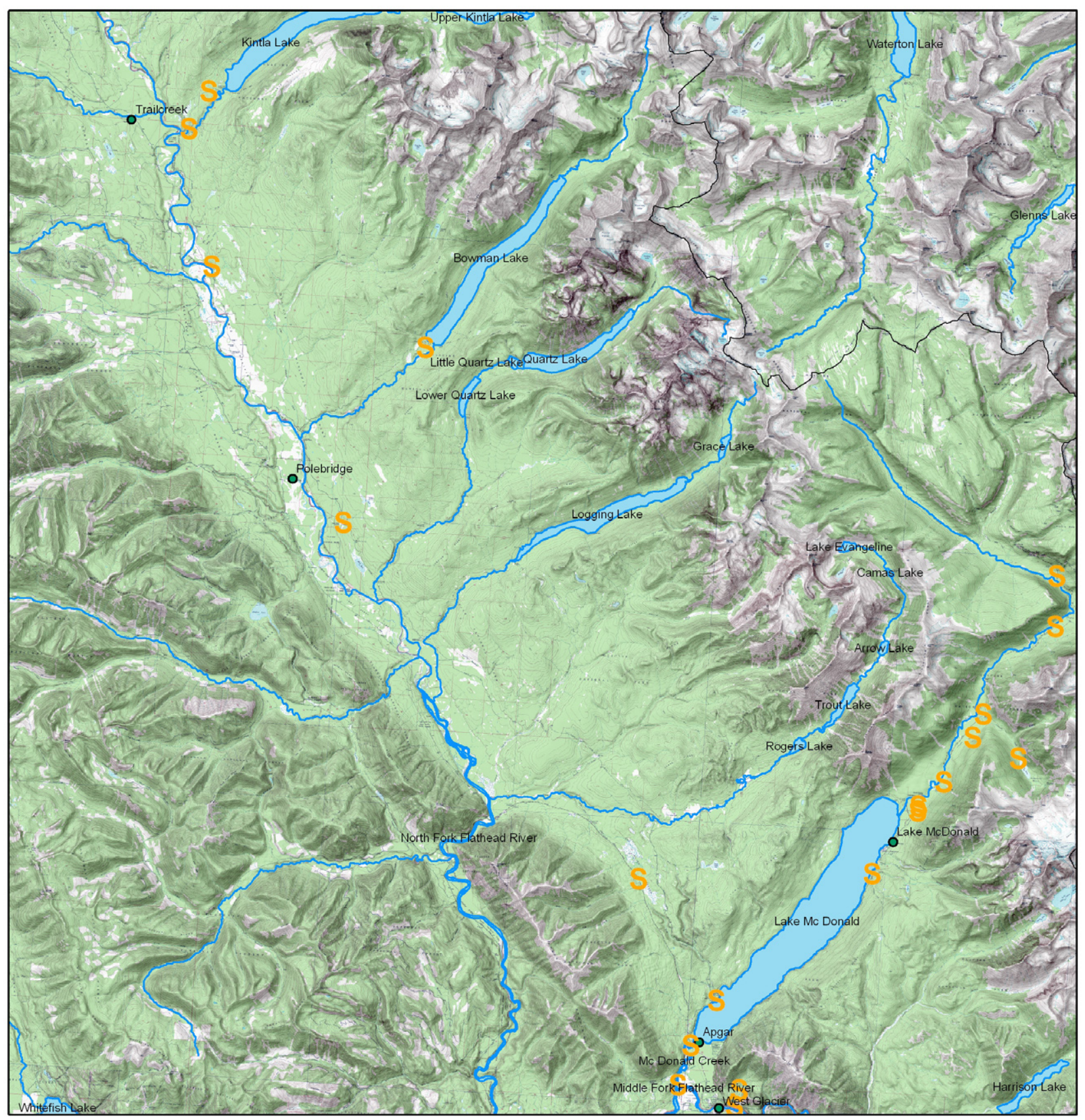

Figure 1. Locations of surveys (S) in Glacier National Park, October 2008. All sites are west of the Continental Divide.

most days, the surveys proved very productive in terms of species diversity, ranging from 0-9 species/site (mean $=4.3$ species), and only one site with no land snails detected. Survey success was due in part because sites with cottonwood and other deciduous canopy species were especially targeted.

Of the 14 terrestrial species included in the 1967 checklist, 12 of these were detected in 2008 (Table 2). Species previously reported and not detected in 2008 were Cross Vertigo (Vertigo modesta) and Shiny Tightcoil (Pristiloma wascoense). Seven species were added to the park checklist, a $50 \%$ increase in the land snail fauna reported from Glacier National Park, and included the state SOC Reticulate Taildropper (Prophysaon andersoni), a G5 S1S2 slug known only from two other locations in Montana: along the Clark Fork River west of Noxon, Lincoln County. 
Table 2. Land snails and slugs encountered west of the Continental Divide in Glacier National during October 2008. An asterisk indicates a species new to the 1967 checklist. Brackets indicate species reported but not during a survey (see Discussion).

\begin{tabular}{|c|c|c|c|}
\hline Common Name & Scientific Name & $\begin{array}{c}\text { Percent (N) } \\
\text { of Sites }\end{array}$ & $\begin{array}{c}\text { Total } \\
\text { Individuals } \\
\end{array}$ \\
\hline \multicolumn{4}{|l|}{ Snails } \\
\hline Suboval Ambersnail & Catinella vermeta & $5 \%(1)$ & 7 \\
\hline Glossy Pillar* & Cochlicopa lubrica* & $10 \%(2)$ & 6 \\
\hline Toothless Column & Columella edentula & $10 \%(2)$ & 2 \\
\hline Forest Disc & Discus whitneyi & $60 \%(12)$ & 108 \\
\hline Brown Hive & Euconulus fulvus & $60 \%(12)$ & 44 \\
\hline Spruce Snail & Microphysula ingersollii & $10 \%(2)$ & 3 \\
\hline Blue Glass & Nesovitrea binneyana & $30 \%(6)$ & 9 \\
\hline Subalpine Mountainsnail & Oreohelix subrudis & $40 \%(8)$ & 61 \\
\hline Ribbed Spot & Punctum californicum & $25 \%(5)$ & 7 \\
\hline Northwest Striate & Striatura pugetensis & $10 \%(2)$ & 3 \\
\hline Lovely Vallonia* & Vallonia pulchella* & $5 \%(1)$ & 3 \\
\hline Western Glass-snail & Vitrina pellucida & $35 \%(7)$ & 17 \\
\hline Quick Gloss & Zonitoides arboreus & $35 \%(7)$ & 29 \\
\hline \multicolumn{4}{|l|}{ Slugs } \\
\hline Brown-banded Arion* & Arion circumscriptus* & $25 \%(5)$ & 29 \\
\hline [Chocolate Arion*] & [Arion rufus $\left.{ }^{*}\right]$ & $--[1]$ & - \\
\hline Dusky Arion* & Arion subfuscus* & $5 \%(1)$ & 2 \\
\hline Meadow Slug* & Derocerus laeve* & $25 \%(5)$ & 11 \\
\hline Giant Gardenslug & Limax maximus & $5 \%(1)$ & 1 \\
\hline Reticulate Taildropper* (SOC) & Prophysaon andersoni* & $35 \%(7)$ & 27 \\
\hline \multicolumn{2}{|c|}{ Total Species and Individuals } & 19 & 369 \\
\hline
\end{tabular}




\section{Discussion}

Four species new to the park checklist are nonnatives, one of which (Chocolate Arion, Arion rufus) is based on a verbal description by park personnel (sighted in the residential area of Park Headquarters at West Glacier) that could only be this large, dark to black slug. Other non-native species in the park include Lovely Vallonia (Vallonia pulchella), Brown-banded Arion (Arion circumscriptus), Dusky Arion (Arion subfuscus), and Giant Gardenslug (Limax maximus). Thus, $23.8 \%$ of the land snail species documented in Glacier National Park are exotics, and $80 \%$ of the exotics are slugs, probably introduced originally and inadvertently in the soil of ornamental plantings and possibly animal feed. All exotics have been found in areas of concentrated human activity (Lower McDonald Creek, Headquarters Area and West Glacier, Avalanche Creek boardwalk, Bowman Lake stock ramp)

Additional species are still likely to be found in Glacier National Park. Foremost would be the native and Montana Potential Species of Concern
Fir Pinwheel (Radiodiscus abietum) and Species of Concern Smoky Taildropper (Prophysaon humile), each of which has been documented near the park boundary on the Flathead National Forest. A high elevation species of mountainsnail (Oreohelix) that is associated with limestone outcrops is possible; other species in this genus have been found in similar limestone sites to the south in the Mission Mountains, Swan Range, Bob Marshall Wilderness, and Scapegoat Wilderness. Additional exotic snails and slugs are also likely to be documented.

Survey results have been entered into the Montana Natural Heritage Program's Animal Point Observation Database. General data summaries for individual species can be seen on the Montana Field Guide and details on the survey locations and species detected can be found on the Montana Heritage Program's Tracker application; links to both can be found in the upper center of the Montana Heritage Program's homepage at http:// mtnhp.org/. 


\section{Literature Cited}

Berry, S.S. 1919. Mollusca of Glacier National Park, Montana. Proceedings of the Academy of Natural Sciences of Philadelphia 71:195-205.

Russell, R.H., and R.B. Brunson. 1967. A checklist of molluscs of Glacier National Park, Montana. Sterkiana 26:1-5. 


\section{Appendix A. Survey locations for land SnaIls in Glacier national Park, Montana, 2008}





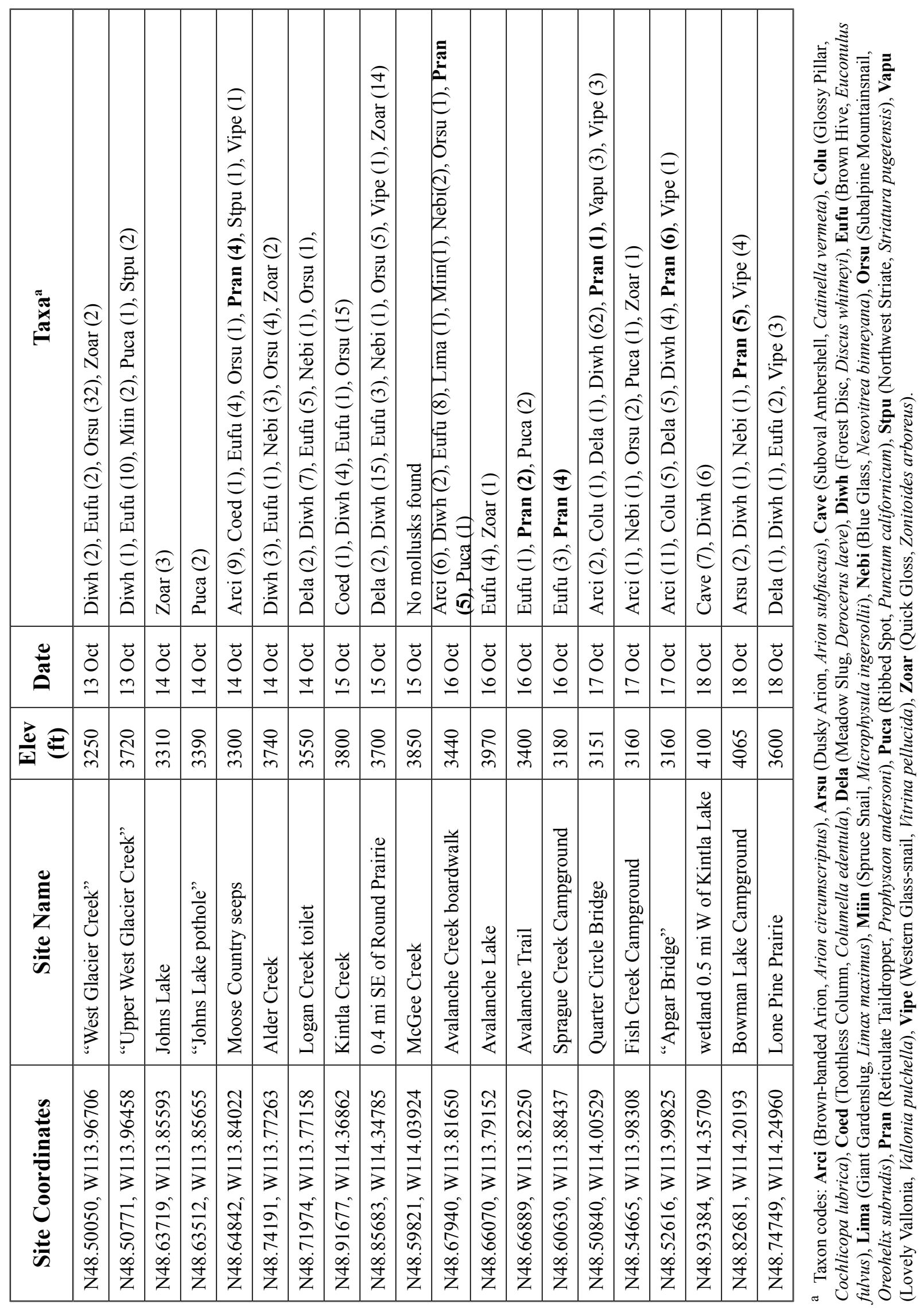





\section{ApPendix B. Illustrated dichotomous KeY tO THE TERRESTRIAL MOLLUSKS DOCUMENTED IN Glacier National Park as of 2008}



Keys are designed for determining mature individuals (a hand lens or dissecting microscope may be useful or necessary for seeing some characters.)

\section{All Terrestrial Mollusks}

1a. Shell absent externally_-go to slug key

1b. Shell present, covering the entire animal—go to snail key

\section{Slugs}

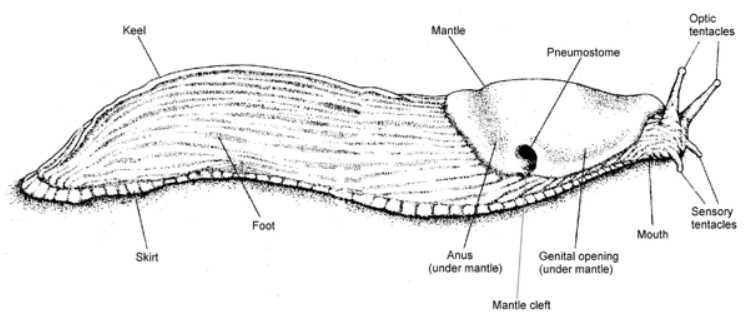

1a. Sole of foot tripartite (having two longitudinal furrows), dorsum of foot sometimes keeled near the posterior end, pneumostome (breathing pore) in posterior half of right mantle margin-2

1b. Sole of foot undivided, dorsum of foot not keeled, pneumostome in the anterior half of the right mantle margin-3

2a. Greater than $50 \mathrm{~mm}$ in length (often much greater), back of foot not keeled, base color tan, variously spotted with black_Limax maximus (Giant Garden Slug)

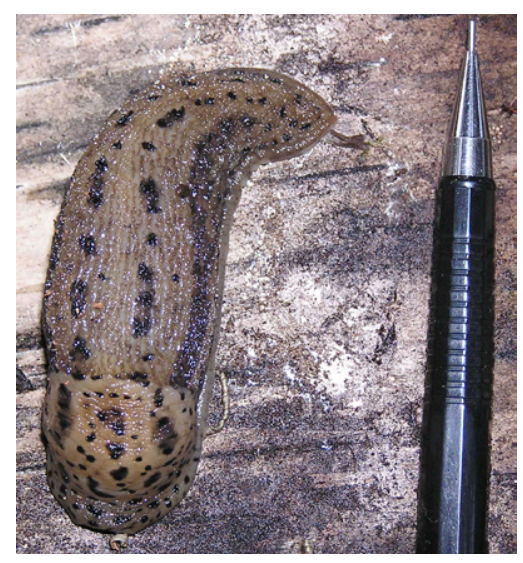


2b. Less than $40 \mathrm{~mm}$ in extended length, back of foot keeled, color brown to nearly blackDerocerus laeve (Meadow Slug)

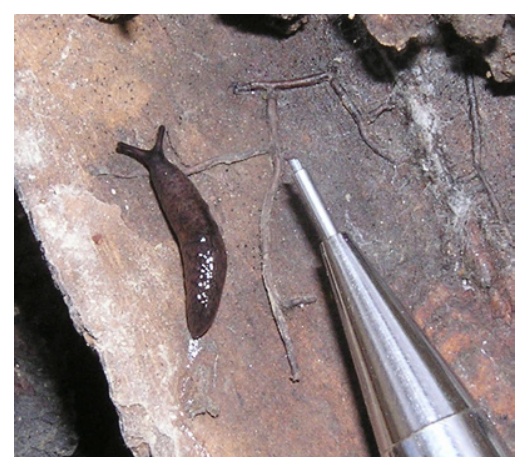

3a. Base color yellowish to pinkish, mantle with dark lateral stripes, back of foot with net-like (reticulate) pattern of black lines, length up to about $50 \mathrm{~mm}$-Prophysaon andersoni (Reticulate Taildropper)

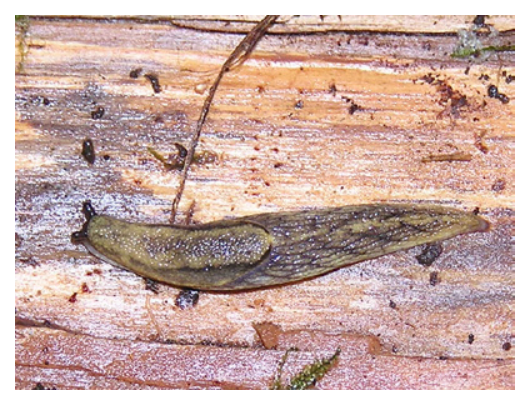

3b. Base color bluish gray, orange, or brown to black, sole generally much paler than upper dorsal) surface, length varies, to $100 \mathrm{~mm}$ or more -4

4a. Base color bluish gray, mantle with small dark spots and dark lateral lines that extend onto the dorsal surface of the foot, length to about $50 \mathrm{~mm}$-Arion circumscriptus (Brown-banded Arion)

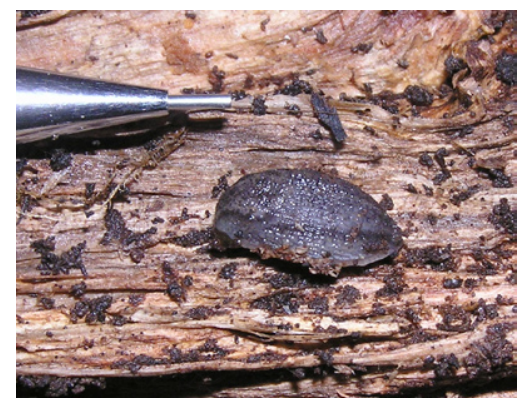

4b. Base color orange or brown to black, length variable -5 
5a. Base color more or less orange, dorsal surface of foot with faint lateral lines, length to about $60 \mathrm{~mm}$ - Arion subfuscus (Dusky Arion)

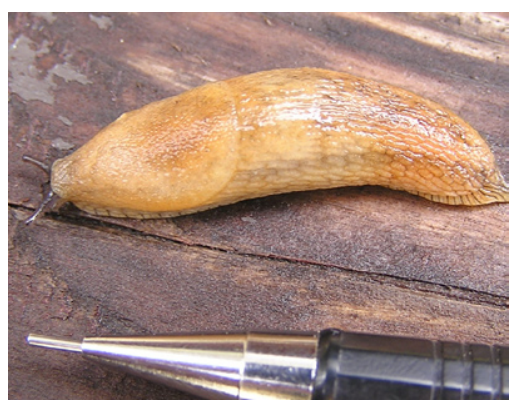

5b. Base color generally brown to black, dorsal surface of foot with prominent longitudinal ridges and furrows, dark lateral bands absent, length to $100 \mathrm{~mm}$ or more-Arion rufus (Chocolate Arion)

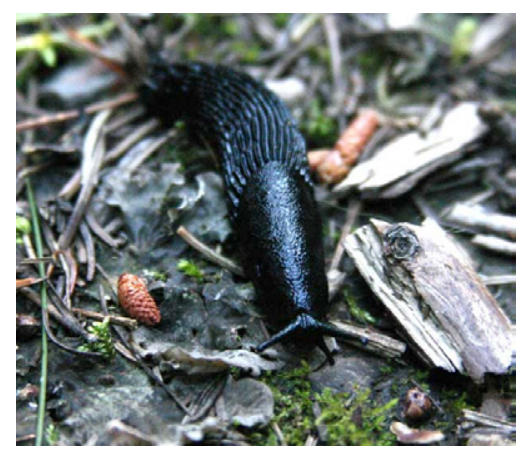




\section{Snails}

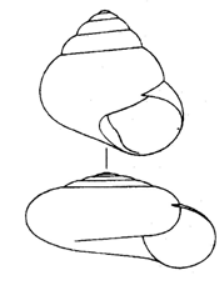

Heliciform

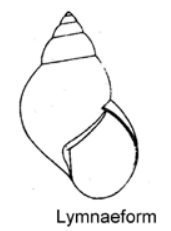

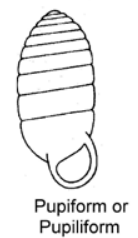

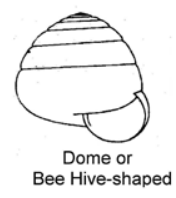

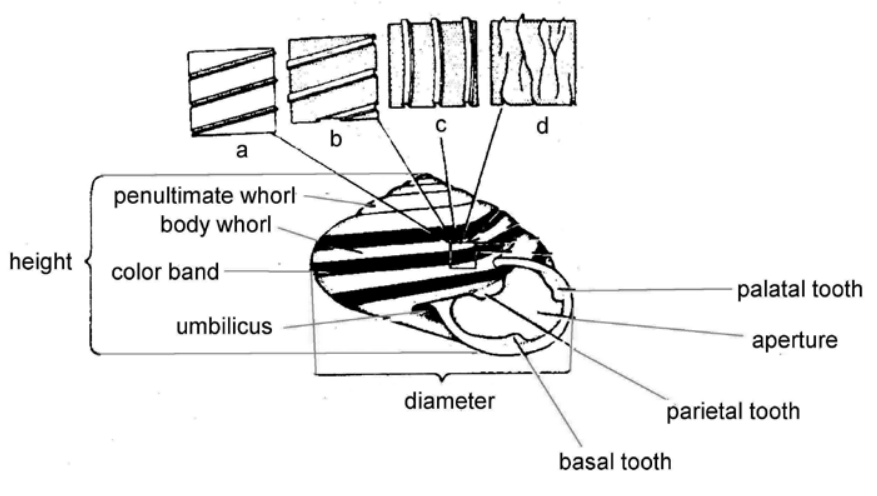

1a. Shell lymnaeform (elongated coiled spire that is sharply pointed), length of spire at least a third of total length, aperture ovate, shell yellowish, surface with very fine file-like markings, about 7-10 mm tall, only in permanent or temporary wetlands-Catinella vermeta (Suboval Ambershell)

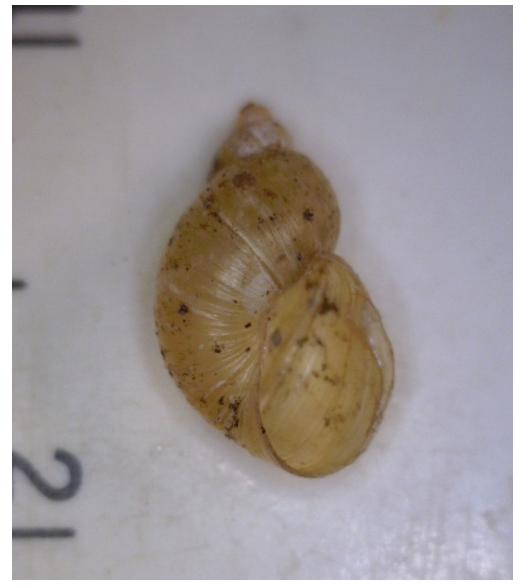

1b. Shell a disk-like coil or beehive shaped, not lymnaeform-2

2a. Shell heliciform (flattened disk-like coil or beehive shape that is wider than tall) -3

2b. Shell pupiform (elongated coiled spire, taller than wide, and with a blunt or rounded tip or apex)-13 
3a. Adult shell with thickened reflected lip (curved back on itself) at aperture, aperture without denticles (small white tooth-like projections), white and size 2-3 mm diameter-Vallonia pulchella (Lovely Vallonia)

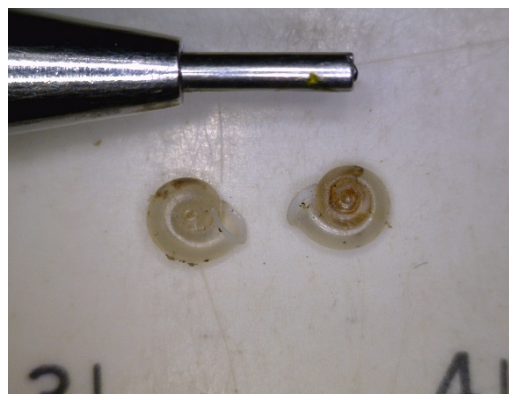

3b. Adult shell without reflected lip at aperture, color and size varies- 4

4a. Shell thin and transparent (clear or amber-colored), generally smooth, less than $10 \mathrm{~mm}$ diameter-5

4b. Shell opaque or with a color pattern, surface generally with ridges (running parallel with coiling) or striae or ribs (running perpendicular to coiling), size variable-11

5a. Shell thin and transparent, smooth, less than $10 \mathrm{~mm}$ diameter with a greatly enlarged body (final) whorl, shell shaped like a tight rams horn_Eitrina pellucida (Western Glass-snail)

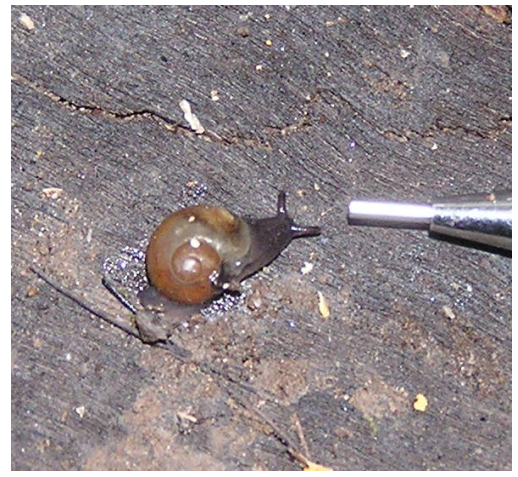

5b. Shell with body whorl not greatly enlarged or only slightly enlarged-6 
6a. Widely umbilicated, width of umbilicus (central depression or pit on the undersurface formed by the layering of the coils) one third or more of the diameter of the shell, less than $2 \mathrm{~mm}$ in diameter and with 3.0-3.5 body whorls, central 1.5 whorls with very fine striations, yellowish-Striatura pugetensis (Northwest Striate)

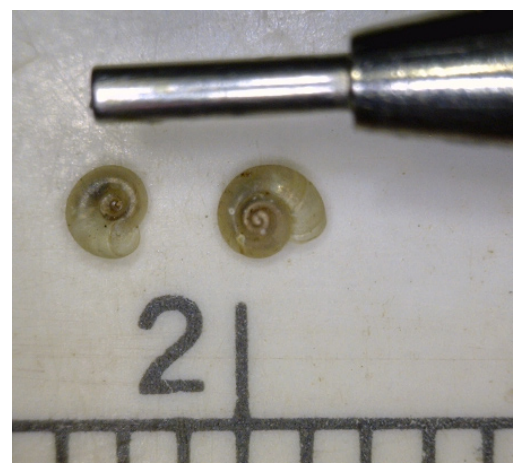

6b. Narrowly umbilicated -7

7a. Whorls about 5 , tightly coiled -8

7b. Whorls not tightly coiled-10

8a. Shell nearly as tall as wide, beehive shaped, amber-colored, about $5 \mathrm{~mm}$ diameterEuconulus fulvus (Brown Hive)

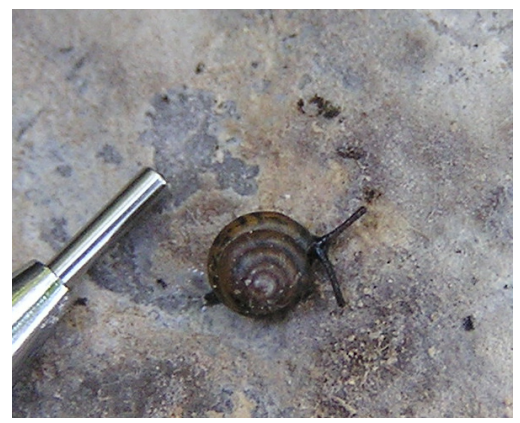

$\mathbf{8 b}$. Height of shell little more than half of the diameter, not beehive shaped-9 
9a. Umbilicus very narrow, shell with less than 5 whorls, aperture narrow crescent-shaped, spire slightly elevated, shell diameter about $3.0 \mathrm{~mm}$, amber-colored-Pristiloma wascoense (Shiny Tightcoil)

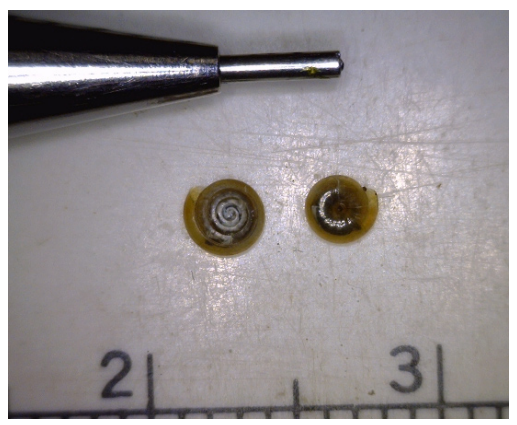

9b. Umbilicus extremely small, shell with more than 5 whorls, spire flat, shell diameter to about $5 \mathrm{~mm}$, whitish-Microphysula ingersolli (Spruce Snail)

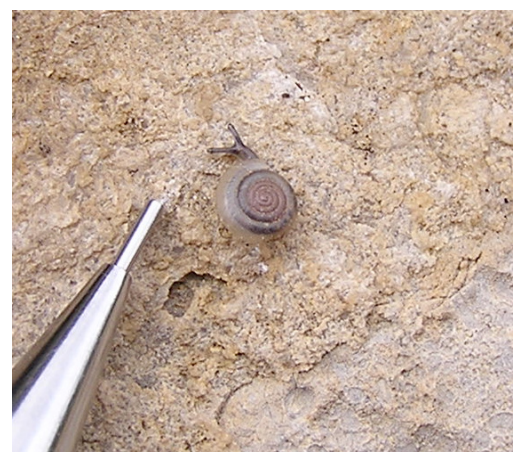

10a. Whorls increasing rapidly in size, the body whorl almost twice as wide as the penultimate whorl, about 3.5 whorls, shell clear and shiny, about $3.7 \mathrm{~mm}$ in diameter-Nesovitrea binneyana (Blue Glass)

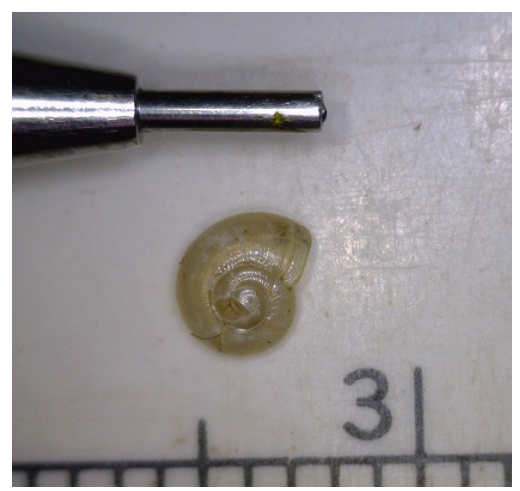


10b. Whorls much the same size, umbilicus somewhat narrow, about 4.0-4.5 whorls, shell amber or horn-colored and cloudy, to about $5.5 \mathrm{~mm}$ diameter-Zonitoides arboreus (Quick Gloss)

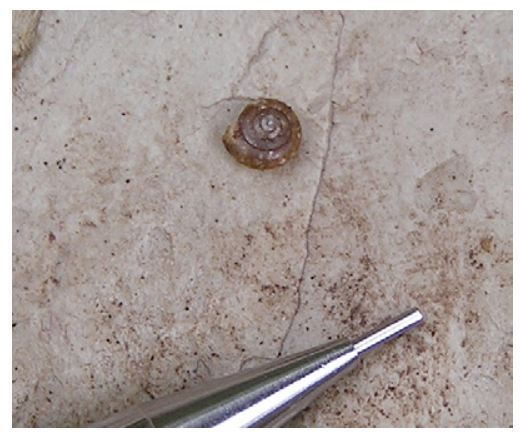

11a. Composition of shell chalky, often with two narrow colored bands on the surface, sometimes a tan base color rather than whitish, large (to about $22 \mathrm{~mm}$ in diameter and 6 whorls)-Oreohelix subrudis (Subalpine Mountainsnail)

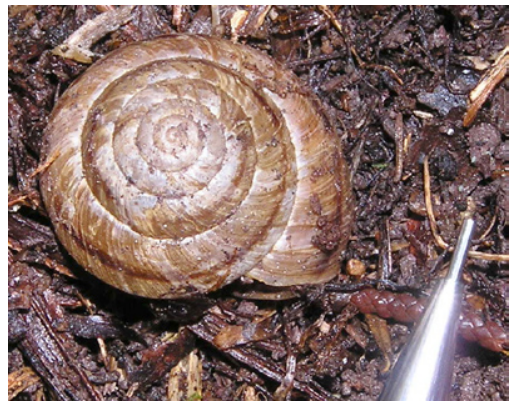

11b. Composition of shell chitinous or horny, color yellowish or brown, shell with many ribs12

12a. Diameter of shell quite small (about 1.4-1.7 mm diameter), somewhat narrow umbilicus, about 3.5-4.0 whorls-Punctum californicum (Ribbed Spot)

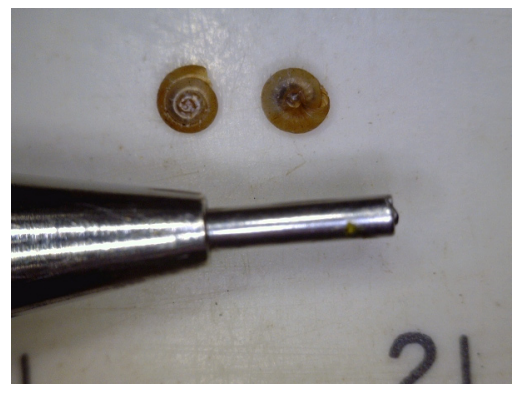


12b. Diameter of shell about 6.0-6.5 mm diameter, somewhat flattened, with about 4.5 whorls, umbilicus somewhat wide (about a third of the diameter)—Discus whitneyi (Forest Disc)

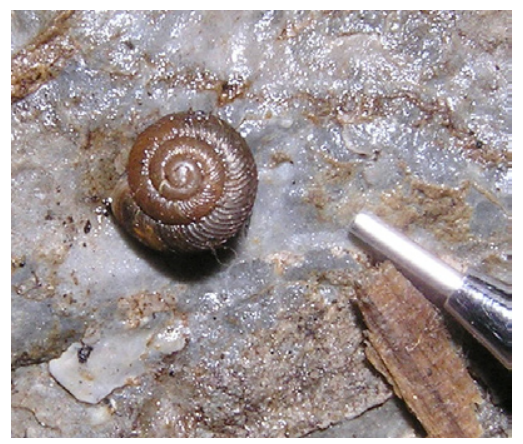

13a. Aperture ovate and usually with 1-5 small denticles (teeth) or rarely with none, 6-7 whorls when mature, shell about 2.4-2.9 mm tall, amber-colored-Vertigo modesta (Cross Vertigo)

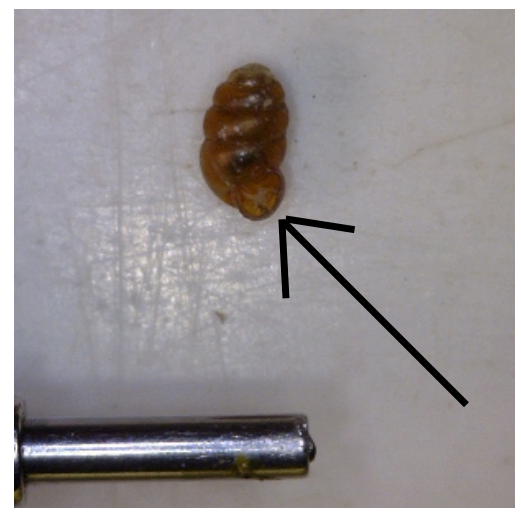

13b. Aperture lacking denticles (teeth) -14

14a. Aperture round, shell about $2.7 \mathrm{~mm}$ tall, 5-6 whorls with the last whorl a little wider than the penultimate whorl, amber-colored_Columella edentula (Toothless Column)

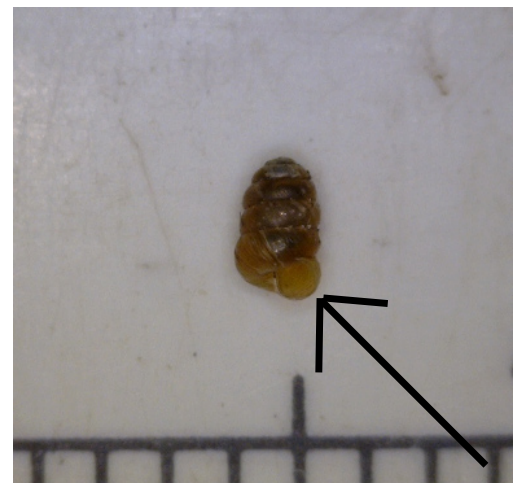


14b. Aperture ovate, shell about 5.0-6.0 mm tall, spire long and blunt, shell glossy and smooth with a thickened aperture lip_Cochlicopa lubrica (Glossy Pillar)

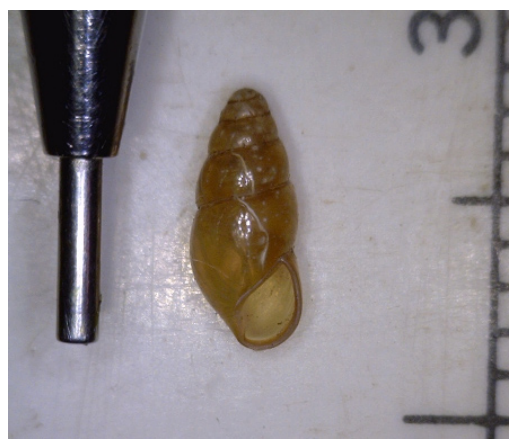

